\title{
TUSOR PÉTER
}

\section{A LEGKORÁBBI PÁZMÁNY-PORTRÉ „REJTÉLYE”}

Pázmánynak - nem mindennapi körülmények között alakuló ${ }^{1}$ - érseksége előtti időszakából két portréfestménye maradt ránk. Az ismertebb, szakáll nélküli arckép keletkezését a Pázmány-ikonográfiával először foglalkozó Vayer Lajos 1605-1615 közé tette (1. kép). ${ }^{2}$ Örzési helye Pannonhalma, ahová a pozsonyi jezsuita kollégiumból kerülhetett, ott a könyvtárat díszítette a szónokok müveinek szekrénye felett. A kollégium épületét 1812-1851 között a bencések használták. Szintén Pannonhalmán található ma az a kép, amelyen Pázmány már a későbbi ábrázolásain is feltünő szakállával jelenik meg előttünk (2. kép). Az 1970-es években magántulajdonból adományozás útján jutott a monostori gyưjteménybe. Első szakirodalmi említése 1988-ból Buzási Enikőtől való, aki az 1. portré leírása közben hivatkozik rá. Stíluselemzési megfontolások alapján az 1. képet Vayerral ellentétben nem tartja eredeti alkotásnak, hanem a 17 . század közepén készült másolatnak, amelynek mintája, előzménye egy ismeretlen, az 1610-es években készült eredeti portré lehet. ${ }^{3}$

Buzási Enikő érvelését erősíti, hogy az 1. képen olvasható felirat valóban a könyvtár adományozására vonatkozik: „R.P. Petrus Pazmany S.I. Postea S.R.E. Cardin. Et A.Ep. Stirg. Biblio. Hanc Collegio Poso. Donavit 1636." ${ }^{4}$ (Lukács és Szabó a kép adományozásáról beszélnek, ami tévedés. ${ }^{5}$ ) Elképzelhető tehát, hogy ezt a portrét tényleg később festették a könyvtár számára (a felirat ilyesmit sugall). Ugyanakkor az, hogy az adományozót rendtagjukként és nem főpapként örökítik meg, furcsa, még akkor is, ha a Társasághoz tartozását akarták is ekképpen hangsúlyozni - ekkor már.

Summa summarum a 2. festmény jelentősége következésképpen még nagyobb, hiszen így ez az egyetlen ismert kortárs portré Pázmányról érseksége elött. Annál különösebb, hogy a leendő prímást nem szokványos jezsuita öltözékben ábrázolja. Pontosabban reverendájának gallérja ${ }^{6}$ és birétuma tipikusan jezsuita kialakítású. Habitusa felett azonban egy fehér csuklyás ruhadarabot visel. A kép alapján lehetetlen eldönteni, hogy egy rövidebb vállgallérröl (mozzetta) avagy egy hosszabb, térden alul érő köpenyről (cappa) van-e szó. Buzási Enikő szerint Pázmány ezen a képen a „szomaszk szerzetesek ruhájában mutatkozik”, és emiatt keletkezését 1616-ra teszi, ám hivatkozást, magyarázatot nem ad közlésében. ${ }^{7}$ Szíves tájékoztatása szerint nem is adhatott, az adatot a főapátsági leltárkönyvből vehette át 1985-1986 körül. ${ }^{8}$

A kép kurrens főapátsági gyüjteményi leírása bármilyen indoklás nélkül - úgy tünik azonban, hogy több információját csupán Fraknóitól merítve - a következőket írja az „1616 körül, olaj, vászon, közép-európai (prágai?) festo"” megjelölésü müről: „A jellegzetes Pázmány-vonásokat viselő mellképen a legfeltünőbb az ábrázolt öltözéke. Pázmány Péter 1614-ben azzal a kéréssel fordult a jezsuita rend generálisához, hogy a személyét ért támadások miatt adjon engedély a Társaság elhagyásához és a karthauzi rendbe való átlépéshez, majd a következó évben azért kért felmentést fogadalmai alól, hogy világi papként élhessen. Az engedéllyel, amely új szerzetesrend választását tette lehetővé számára, 1616 áprilisában élt, amikor a pápa kívánságára [!] a szomaszka rend tagjai közé állt. Ennek a rendnek a ruházatát viseli a képen - s noviciátust kezdett a prágai nuncius vezetésével. Új rendi köteléke bizonyosan megkönnyítette még ugyanezen év szeptemberében esztergomi érseki kinevezését is." 9 


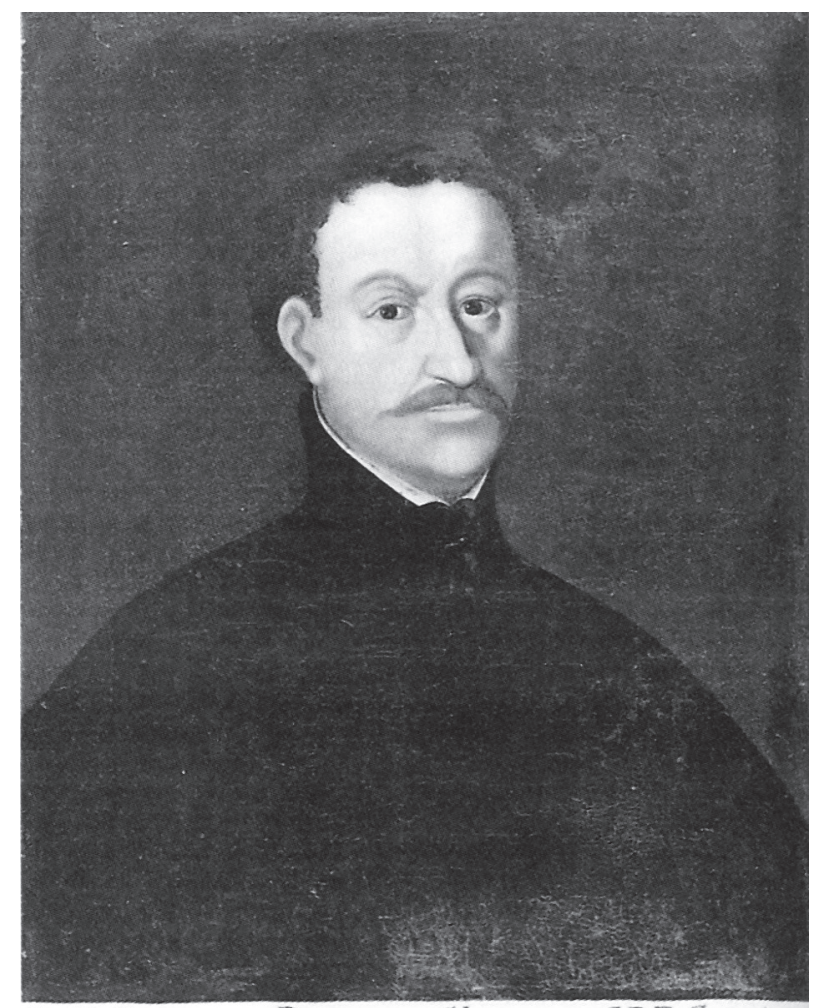

R.P PETRUS PAZMANY SIPOSTEA SRE. CARDINE

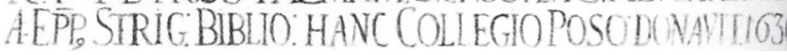

1. Pázmány Péter arcképe, 17. század közepe. Pannonhalma, Föapátsági Gyüjtemény

Gyakorlatilag ugyanez a szöveg található a kép legnívósabb és legrangosabb fekete-fehér nyomtatott publikációja mellett is. Első bekezdése bővebb, a végén pedig záradék egészíti ki: „A jellegzetes Pázmány-vonásokat viselő, kissé jobbra forduló mellképen a legfeltűnőbb az ábrázolt öltözéke. Fején fekete birétumot hord, a szintén fekete ruhája fölé csuklyás fehér köpeny járul. E habitus nem azonos sem a jezsuita rend ruházatával, sem a Pázmány által 1616-tól betöltött esztergomi érseki méltóság jelvényeivel... A portré, amelynek reprezentációs módja a Pázmány-ikonográfiában ismeretlen, talán Pázmány Péter jezsuitáktól elhatárolódó állásfoglalását hordozza egyúttal az új rendbe való átlépését is dokumentálva, de az sem zárható ki, hogy a szomaszka szerzetesek kezdeményezték az érseki méltóságra jutott rendtársuk saját öltözékükben való megfestését." ${ }^{10}$ Hivatkozásként Buzási 1988-as közlése került feltüntetésre. Ezzel a kör bezárult, a „szomaszka-sejtés" forrása a szakirodalomból nem azonosítható. Eredete, most már tudjuk, a főapátsági gyüjteményi leltárkönyvre vezethető vissza.

A legújabb Pázmány-ikonográfia a kritika halvány nyoma nélkül, tényként állítja: „A legrégebbi fellelhető Pázmány-portré a leendő érseket, fiatal korában, a szomaszka rend öltözetében ábrázolja...
Fontos lépés volt tehát a tanító rendhez csatlakozás, hiszen jezsuitaként nem nevezhették volna ki érsekké. Ezért lehetséges, hogy ebben az öltözetben örökítették meg. A szúk képkivágás az arc és öltözet puritánságát hangsúlyozza."11

Dolgozatunkban ezt az önmagába visszatérő, eddig soha senki által meg nem kérdőjelezett állítást akarjuk cáfolni úgy, hogy helyébe új interpretációt adunk.

A szomaszka-értelmezést, ezt a tudomány számára a jelek szerint magától értetődő tézist már régóta megfejtésre váró talányként, valóban szinte „rejtély"-ként tartottuk számon. Hiszen ha a korszakkal foglalkozó történészként szemügyre veszszük a képet, első pillantásra feltünik, hogy a fehér csuklyás ruhadarab meglehetősen szokatlannak számít a kora újkorban alakult, újabb típusú szerzetesrendek körében. Figyelembe véve, hogy „reverendája" felett viseli Pázmány, nem tekinthetô egy másik rend habitusának (alapruházatának), hanem inkább egy kiegészítő ruhadarabnak. Szemlátomást egy úgynevezett mozzettáról van szó, amely a reneszánsz időkben alakult ki hosszabb, köpönyegszerü elődjéből, a cappából. Míg a cappa használata viszszaszorult, rövidített változata, a vállgallérszerú mozzetta mindinkább elterjedt. Más-más színben, változatban viselték bíborosok, püspökök és más prelátusok, monasztikus és kanonokrendek tagjai. ${ }^{12}$

A képen látható változat színe alapján leginkább a candidus ordo, a premontrei kanonokrend középkorias és korabeli öltözékével mutat hasonlóságot a Közép-Európában a kora újkorban előforduló rendek közül. ${ }^{13}$ Ha képzőmúvészeti párhuzamot akarunk keresni, Zásio András (1741-1816) jászói prépost arcképén hasonló capucinumos fehér vállruhát figyelhetünk meg. ${ }^{14}$ A Pázmány által felöltött ruhadarab tehát egyáltalán nem szokatlan viselet. Hasonló formában még a 18-19 században is használatban volt a premontreieknél. ${ }^{15}$

A szomaszka-sejtéssel kapcsolatos kételkedésünk felerősödik, ha az idevágó történeti forrásokat is kézbe vesszük. A majdani prímás és a szomaszkák kapcsolatának alakításában meghatározó szerepet játszó római császári ügyvivő, Lodovico Ridolfi ugyanis kifejezetten azt írja 1616. február 20-ai jelentésében, hogy a szomaszkák rendi öltözékükben, szabályaikban igazából nem különböznek a jezsuitáktól. ${ }^{16}$ Ha utánanézünk a témával foglalkozó modern szakirodalomnak, kétségünkből egyenesen gyanú válik. A történeti leírás szerint ugyanis a szomaszkák más szerzetesekhez hasonlóan akkurátusan szabályozott öltözékének a színe olyannyira 
egyetemlegesen a fekete, hogy még az alsónemünek is ilyen anyagból kellett készülnie. ${ }^{17}$ Felvetődhet, hogy esetleg a rend novíciusai hordtak átmenetileg fehér öltözéket. Utánaérdeklődtünk: sem a szomaszka iratokban, sem a hagyományban nincs nyoma ennek. ${ }^{18}$

A portré szomaszka értelmezését következésképpen ki kell zárnunk. Arról sem lehet szó tehát, hogy Pázmány, akiről tudjuk, sosem öltötte - miután végre 1616 júniusára megérkezett, kijelölt elöljárója, a nuncius eltávoztával nem is ölthette - magára a neki megküldött szomaszka habitust, ${ }^{19}$ esetleg lefestette magát a rend öltözékében, hogy így is dokumentálja: nem tartozik a jezsuitákhoz.

Mi tehát a vitathatatlanul Pázmányt ábrázoló kép megfejtése? Nem szokványos jezsuita ábrázolás, nem is érseki, sem nem szomaszka. Azt a feltétezést, hogy a fehér csuklyás, kapucnis ruhadarab csupán esetleges viselet lenne (például a hideg miatt), rövid úton elvethetjük. Nem egy véletlenszerü fényképfelvételről van szó, hanem egy megkomponált alkotásról. Azt a másik végletes, a „reprezentáció, identitás és önkifejezés a kora újkorban" jeligére - számunkra elég nehezen - adódó értelmezést szintén kizárhatjuk, miszerint Pázmány a rá szórt rágalmak ellenében, azok cáfolatára festette meg magát fehér öltözékben, hogy így is hangsúlyozza ártatlanságát. Ugyanígy elvethetjük azt a csupán formál logikailag adódó értelmezést, hogy átlépési szándékát a karthauzi rendbe kívánta volta ilyesformán megörökíteni.

Mi lehet hát a "rejtély” nyitja? Azt biztosra vehetjük, hogy a képnek 1616-ban kellett készülnie. A „,nyilvános” jezsuita korszak után és az érsekség előtt. Ez a két helyes eredo, amelynek - láthattuk téves vetülete a szomaszka értelmezés, már csak egyetlen egy irányt tud kijelölni számunkra. Pázmánynak a felsoroltak mellett, a bíborosi méltóságot leszámítva, csupán egy szóba jöhető egyházi „állapota" volt, ez pedig nem más, mint a turóci prépostság. Vagyis a fehér ruhás kép kizárásos alapon, logikai úton megközelítve nem ábrázolhatja másként Pázmányt, csakis mint turóci prépostot. Így keletkezését egészen pontosan 1616. április 25. utánra tehetjük. Nagy valószínűséggel valóban Prága lehet a megfestés helye. Mivel tudjuk, hogy kinevezése után Pázmány szinte folyamatosan úton van: a Prága-Bécs-Pozsony-Turóc-Prága (június elejéig), majd a Kassa-Prága-Bécs-Prága távokon mozog, hosszabb időt egy helyben csupán augusztus első harmadától tölt a cseh fóvárosban, 1616. augusztus-szeptemberben ülhetett modellt az ismeretlen mesternek. Vagyis a festmény vélhetően az érseki kinevezés publikálása előtti $4-5$ hétben készülhetett.

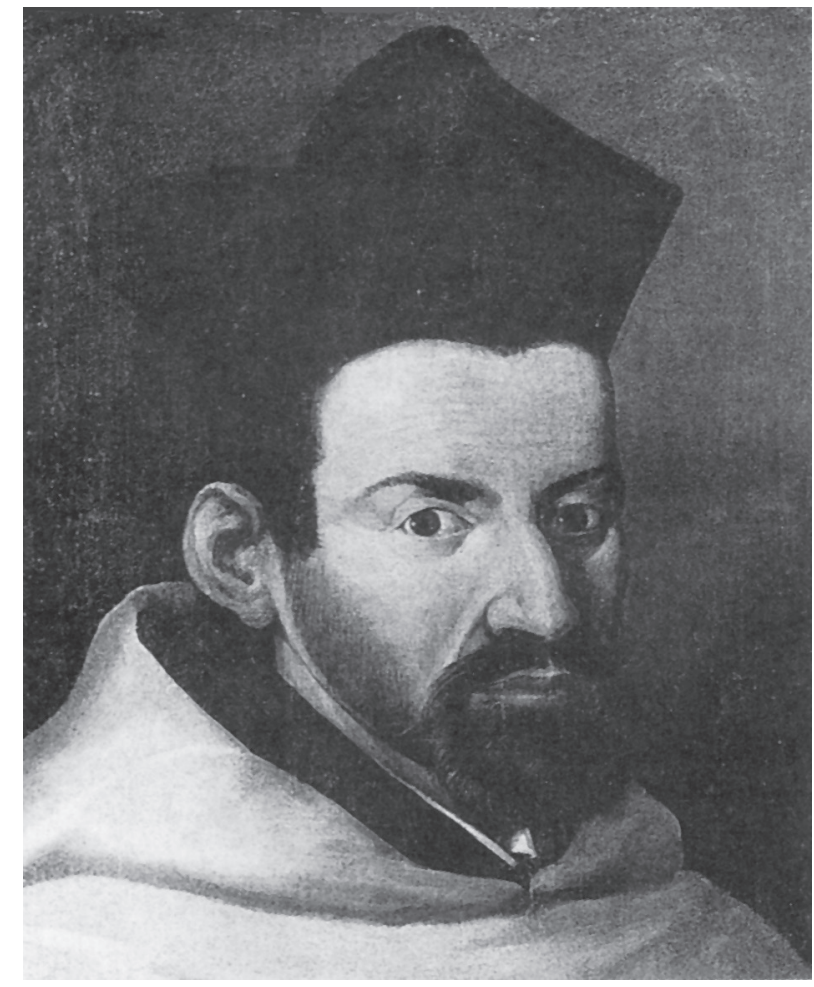

2. Pázmány Péter mint turóci prépost, 1616.

Pannonhalma, Föapátsági Gyüjtemény

De még alaposabban tovább gondolva a kérdést, szem előtt tarthatjuk, hogy 1616 decemberéig, amíg pápai megerősítésének hírét nem vette, Pázmány - a kinevezését követő napokat leszámítva - következetesen nem esztergomi érsekként írta alá leveleit. Ezért is feltételezhetjük, hogy nem követte el azt a Róma által kifogásolt visszaélést, ${ }^{20}$ hogy uralkodói kinevezés után, pápai megerősítése előtt püspöki öltözéket öltött volna, ${ }^{21}$ vagy netán bármilyen liturgikus fópapi jelvényt viselt, használt volna. ${ }^{22}$ Ebben az esetben viszont a kép az érseki kinevezés megörökítésre nem éppen indokolatlan alkalmából készülhetett, véleményünk szerint továbbra is Prágában, ahonnan Pázmány november első napjaiban kelt útra. Javadalma átvételével bajlódva aligha lehetett már erre ideje, lehetősége Bécsben, Pozsonyban, Nagyszombatban. ${ }^{23}$

A kizárásos következtetés, bár önmagában nem kevés, természetesen további bizonyításra szorul. Tudjuk, hogy Pázmány külsőségekben is kifejezésre kívánta juttatni, hogy úgymond „már nem jezsuita többé". Miután a nuncius joghatósága alá került, gallérját reverendája fölé kihajtva, világiasan viselte, a nyilvánosság előtt szakállát megnöveszt$v^{24}{ }^{24}$ kezén kesztyűvel, legtöbbször szolga kíséretében jelent meg - olvashatjuk Vitelleschi jezsuita generális 1616. május 28-án kelt panaszát, ${ }^{25}$ ami Pázmánynak március végétől április végéig tartó 


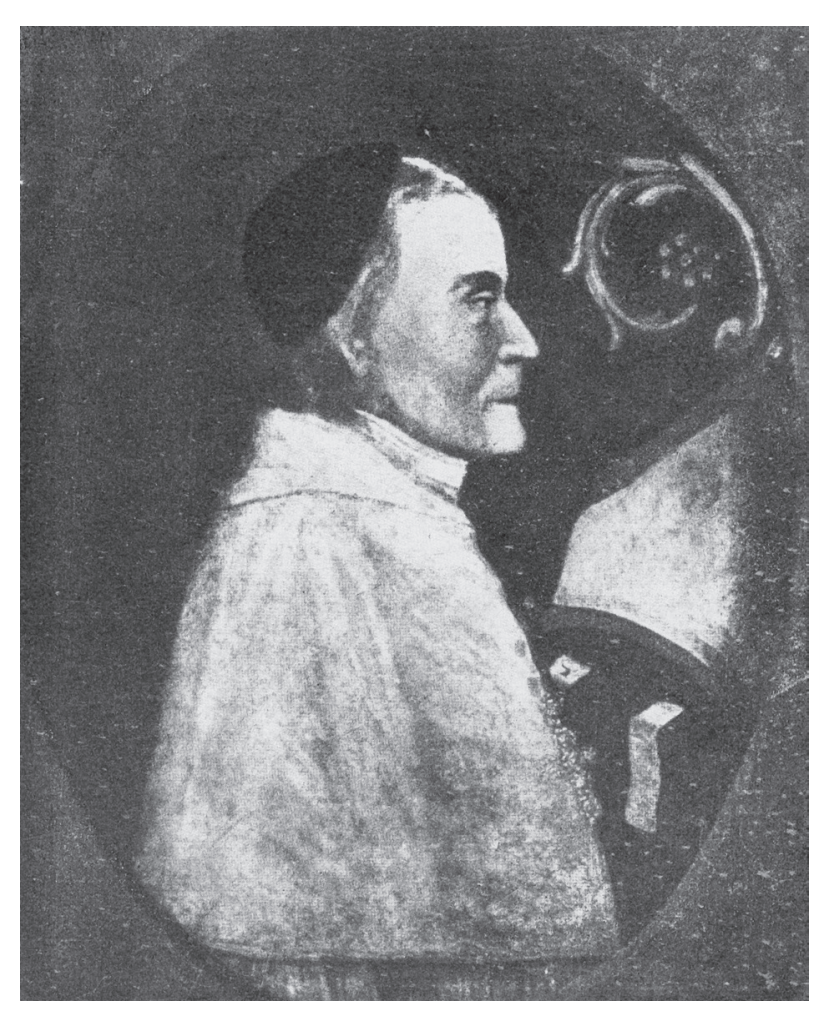

3. Zásio András jászóvári prépost (1741-1816) arcképe. Reprodukció

prágai időszakára vonatkozik. Turóci préposti kinevezése után ugyanis napokon belül elhagyta a császári székhelyt. Kérdés tehát, hogy mindennapi viseletében hogyan juttathatta ezután kifejezésre új rangját, állapotát? ${ }^{26}$ Ez feltétlenül szükséges volt, május-júliusban a fél Királyságot beutazta, és kassai küldetése egyik fó motivációjának épp azt tarthatjuk, hogy ország-világ megtudja: semmi törvényi akadálya nincsen már annak, hogy Pázmányt ki lehessen nevezni Magyarország prímásává, hiszen már nem jezsuita többé. ${ }^{27}$ Ha viszont a többi kortárs apáthoz, préposthoz hasonlóan díszesebb, föpapi öltözéket viselt volna, az egyszerünek aligha nevezhető szerzetesi állapotával összefüggésben tünhetett problematikusnak. ${ }^{28} \mathrm{~A}$ jezsuiták már kihajtott fehér gallérja és kesztyüviselete miatt is felháborodtak. ${ }^{29}$

A képi ábrázolás szerint úgy tünik, Pázmány egy nagyon kézenfekvő, kreatív megoldással hidalta át a nehézséget, és préposti javadalma szerzetesi eredetéhez nyúlt vissza. A turóci prépostság ugyanis, elégedetten nyugtázhatjuk, eredetileg premontrei alapítás volt..$^{30}$ Éppen arról a rendről van tehát szó, amelynek korabeli viseletével a festményen látható, első pillantásra titokzatos fehér ruhadarabot leginkább azonosíthattuk. Turócot utolsó prépostja, Majthényi Uriel már az 1530-as években elzálogosította a Révayaknak, a premontreiek az 1550-es években hagyták el a prépostságot. ${ }^{31}$ Visszaváltását követően az udvar egyszer sem töltötte be a javadalmat, és miután 1586-ban birtokait a jezsuiták megkapták, még kevésbé. Majthényi után a - Forgáchféle közjátékot is figyelembe véve ${ }^{32}$ - az első önálló, kinevezett prépost Pázmány. Ô akár a közelben töltött vágsellyei évei okán, akár olvasmányaiból ${ }^{33}$ tudhatta, hogy voltaképpen a premontrei prépostok örökébe lépett. A katolikus főrak 1610-ben az uralkodónak benyújtott emlékirata kifejezetten párhuzamot von a premontreiek és a jezsuiták között, mondván: ahogy IV. Béla a premontreiek számára alapította Turócot, úgy azok távoztával az országból Mátyás a Társaságnak adományozhatja azt, bármilyen megkötés kegyúri joga sérelmét jelentené. ${ }^{34}$

Turóc premontrei hagyományát tehát élőnek tekinthetjük a 17. század elején. Pázmánynak a hírneves prágai strahovi premontrei kolostorból $l^{35}$ pedig aligha lehetett nehéz beszerezni a képen látható fehér mozettát. Ennek gombok nélküli változata, szabása megegyezik a rendben belül 1650 előtt használt típussal. ${ }^{36}$ A franciaországi Abbaye Saint-Martin de Mondaye szerzetesi máig olyan vállruhát hordanak, mint amilyen Pázmány festményén látható. ${ }^{37}$

Biztosra vesszük, hogy a leendő érsek turóci prépostként sem a többi magyarországi prépostnál, apátnál szokásos gyürüt, mellkeresztet nem viselte, ${ }^{38}$ és még ünnepélyes miséi során sem használt mitrát és pásztorbotot. ${ }^{39}$ Igyekezett megőrizni szerzetesi jellegét, és élve a régóta formálódó államegyházi szisztéma nyújtotta lehetősséggel (Zsigmondtól kezdve a premontrei prépostokat is a magyar királyok nevezték ki), ${ }^{40}$ az átmeneti időre nem a júniusban megérkező szomaszka öltözéket, hanem beneficiuma eredeti rendjének öltözékét öltötte magára. Jelképesen és „,szerzeteshez méltóan” fenntartotta, védte szerzetesi jellegét, úgy a külvilág, mint lelkiismerete elött. Ez az értelmezés azt is jelenti számunkra, hogy Pázmány turóci préposti kinevezésének napján - érseki előléptetéséhez jezsuitasága miatt szükséges ${ }^{41}$ - szomaszka novícius-jelöltségét tulajdonképpen befejezettnek tekintette.

Nem tudunk utánajárni, de nem zárjuk ki azt sem, hogy szó sincs ennyire kreatív megoldásról, és Pázmány nem tett mást, mint a Fátra hegyei között élő gyakorlathoz alkalmazkodott. Ne feledjük, hogy a turóci prépostság nem csak javadalmában létezett, ősi hiteleshelyi tevékenységét folytatólagosan világi papokból álló társaskáptalan végezte. ${ }^{42}$ Megkülönböztető jegyként, kanonoki jelvényként talán ők is tovább örökíthették a premontrei kanonokok e sajátos viseletét. ${ }^{43}$

Mindenestre fogalmazzuk meg a kép értelmezésének új tézisét: az 1970-es években előkerült, Pannonhalmán őrzött portré Pázmányt jezsuita 
habitusban és birétumban ábrázolja. A vállán viselt fehér mozzetta szerzetesi eredetü prelátusi jelvényként - eredetileg premontrei alapítású - turóci préposti méltóságát fejezi ki. Keletkezése 1616. április 25-e és szeptember 28-a (illetve amennyiben kifejezetten az érseki kinevezés alkalmából készült, november eleje) közé, Prágába tehető. A kompozíció jelképes értelmezést is lehetővé tesz számunkra: Pázmány vonásait hitelesen megörökítve a premontrei alapítású, 1586-tól a rend megszüntetéséig jezsuita tulajdonú turóci prépostság sajátos, kettős premontrei/jezsuita jellegét szimbolizálja. ${ }^{44}$

\section{JEGYZETEK}

1 L. erre most lezárásra kerülő kéziratomat: Tusor Péter: Egy „epizód” Magyarország és a római Szentszék történeti kapcsolataiból. Pázmány Péter esztergomi érseki kinevezése (Mikropolitikai tanulmány). Budapest 2013. Közleményem témája e monográfia munkálatai közben körvanalazódott előttem. Kutatásaimat az OTKA (NN 82 307), továbbá a Magyar Tudományos Akadémia támogatta (MTA-PPKE „Lendület" Egyháztörténeti Kutatócsoport). - Itt köszönöm meg Galavics Géza és Buzási Enikő szíves segítségét, kritikáját.

2 Pannonhalma, Bencés Főapátság, Múvészeti Gyüjtemények, vászon, olaj, $81 \times 60 \mathrm{~cm}$. Ifj. Vayer Lajos: Pázmány Péter ikonográfiája. Budapest 1935, 16. - A kép két újabb közlése és ismertetése in: Lukács László - Szabó Ferenc szerk.: Pázmány Péter emlékezete. Halálának 350. évfordulójára. Róma 1987, műnyomó melléklet a címlap előtt; Takács Imre szerk.: Mons Sacer 996-1996. Pannonhalma 1000 éve I-III. Pannonhalma 1996, III., 118-119 (A.90. sz.). - Köszönöm Borián Elrédnek a pannonhalmi portrékkal kapcsolatos tájékoztatását.

3 Pannonhalma, Bencés Főapátság, Múvészeti Gyüjtemények, vászon, olaj, $49 \times 40 \mathrm{~cm}$. Buzási Enikó: Régi magyar arcképek. Kiállításkatalógus. Tata-Szombathely 1988, 21-22.

4 Feloldása: „R[everendus] P[ater] Petrus Pazmany S[ocietatis] I[esu] postea S[anctae] R[omanae] E[cclesiae] C[ardinalis] et A[rchi]ep[iscopus] Strig[oniensis] Biblio[thecam] hanc Collegio Poso[niensi] donavit 1636".

5 I. h. - A felirat második felének rövidítését ehhez az értelmezéshez át kellene alakítani, és ki kellene egészíteni, ráadásul a szórend is szokatlan lenne így: biblio[thecae] hanc [sclt. picturam] collegii Poso[niensis] donavit 1636".

6 Hajszálpontosan olyan, mint például az 1582-ban született Goswin Nickel ismert ábrázolásáé, aki 1652 1664 között volt a rend generálisa. Vö. Joachim Schäfer: Ökumenisches Heiligenlexikon, 2010, ord. alph. (online publ.).

7 Buzási i. m. 22.

8 Buzási Enikő szíves közlése szerint a portré 1985/86 táján egy, Pannonhalmán végzett fotózás alkalmával került elé, amikor felvétel készült róla.

$9 \mathrm{http}: / /$ collections.osb.hu/cgi-bin/ targy? targy=83\&kep=fest_92.html (2011. január 3.).

10 Mons Sacer 996-1996 ... i. m. III., 118. (A.89.)

11 Babucsik Anna: A Pázmány-ikonográfia új kérdései. In: Textológia és forráskritika. Pázmány-kutatások 2006ban. (Pázmány Irodalmi Múhely. Tanulmányok, 6. Szerk. Hargittay Emil.) Piliscsaba 2006, 139-166, 141. A kép közlése a 148. oldalon, színesben pedig a kötet borítóján. A szerző hivatkozása: „Sávai, Pázmány és a szomaszkok, 123-141". Innen azonban egyáltalán nem derül ki, még utalás sincs rá, hogy milyen a szomaszkák viselete. Sem Buzási Enikőt, sem a Mons Sacert, sem a pannonhalmi katalógust nem idézi.

12 Egyes nézetek szerint az alapértelmezésben kapucnis (cum capucino, cum cucullo) mozzetta nem a cappa rövidüléséből, hanem a fejet, nyakat, vállat szorosan beburkoló almutiumból veszi eredetét. Vö. „Mozzetta”, Catholic Encyclopedia, ord. alph.; "Almutium”, MeyersKonversationslexikon, ord. alph. Utóbbit én inkább a kizárólag karinggel (superpelliceum), oltárnál használatos mycetummal hozom rokonságba.

13 Giancarlo Rocca: «La sostanza dell'effimero» Gli abiti degli Ordini religiosi in Occidente. Roma 2000, passim, a premontreiekre Leo Cyrillus van Dyck áttekintése: 240-246 (scheda 52). (A kötetre Msgr. Sergio Pagano hívta fel figyelmemet. Megszerzésében Christine-Maria Grafinger volt segítségemre.) - Francisco Suarez szerint a premontrei viselet alapvetően a lokális kanonoki öltözékhez igazodik: „Ordinem hunc in principio fuisse canonicorum regularium reformatorum, quamvis non constet, an in prinicpio usi fuerint religiosi communi habitu canonicorum regularium vel aliquo proprio habitu monachiali. Nunc vero huiusmodi habitum deferunt, praesertim in Hispania, in aliis vero provinciis canonicorum rochetum, seu lineam vestem albam deferre dicuntur, quia iuxta sua statuta possunt in hoc consuetudini uniuscuiusque regionis sese accommodare." Tractatus nonus. De varietate religionum, tam in genere quam in specie, lib. I, cap. V, 6 (vö. Francisci Suarez opera omnia, i. m.): „De ordine Praemonstratensium". Vö. Basilius Franz Grassl: A premontrei rend szentjei. Budapest-Csorna 1941, 5; Kovács Imre Endre - Legeza László - Török József: A premontreiek. Budapest 2002, 14. is.

14 Hermann Egyed: Zásio András jászói prépost tanári és teológiai irodalmi munkássága. In: Emlékkönyv Szent Norbert halálának 800 éves jubileumára (1134-1934). Gödöllő 1934, 203-238, a p. 208. utáni műnyomó melléklet; korábbi közlése: A jászóvári premontrei kanonokrend jubileumi névtára 1802-1902. Történeti bevezetéssel. Budapest 1902, p. 34. utáni múnyomó melléklet; későbbi: Kovács, A premontreiek... i. m. 83. képmelléklet. - L. itt a 3. számú képet.

15 Vö. Kovács-Legeza-Török i. m. 84. és 85. képmelléklet (Bernát Miksa [1817-1829] és Richter Alajos [18301854] jászó prépostok). - Megjegyzem, hogy nem autentikus képi ábrázolások alapján avatatlan szem számára hasonló viseletnek tünhet a pálosok viselete is. A magyar pálosok azonban az 1644-es reform elött, amely a teljes fehéret írta elő, a fehér tunikán fekete skapulárét és fekete capucinumot hordtak. Rocca i. m. 408-409 (Janusz Zbudniewek írása). A rend korabeli, reform előtti viszo- 
nyai, illetve a dignitalis/beneficialis jelleg hiánya, továbbá Pázmány személyes viszonyulása hozzájuk, főként érseksége első éveiben az előző információ nélkül is e szál elejtését tanácsolják. Vö. Galla Ferenc: A pálosrend reformálása és a Szentszék. (Klny. Regnum Egyháztörténeti Évkönyv 1940-1941.) Budapest 1941, passim.

16 Wien, Österreichisches Staatsarchiv, Haus-, Hofund Staatsarchiv, Handschriftensammlung, Ms. W 290, vol. 13, fol. 545rv. („Tanítórendként” való aposztrofálásuk a szakirodalomban nem felel meg a történeti valóságnak. Vö. Babucsek i. m.) - A kurrens szakirodalomban a kora újkori szerzetesrendek öltözéke leírásának a következő fejezetcímet találjuk: „Il non abito dei Chierici regolari” (teatini, barnabiti, somaschi, di Gesu, chierici regolari della madre di Dio, camilliani, caracciolini, scolopi). Rocca i. m. 449-472. Vagyis e szerzeteseknek - teatinusoknak, barnabitáknak, jezsuitáknak, piaristáknak stb. - tulajdonképpen nincsen kifejezett, sajátos habitusuk.

17 Bár a legrészletesebb szabályozás 1626-ból való, ez nyilván csak pontosítja, részletezi az 1591-es konstitúciókban foglaltakat: „Per i sacerdoti la tomaca doveva arrivare sino ai piedi, e, davanti, essere d'un tessuto unico sino alla cintura, il collare essere stretto da almeno due gancettini in modo non lasciar trasperire né il collo né la gola. Le maniche non dovevano essere tenute strette nè da ganci, nè da bottoni, ma lasciate molto ampie. Le cinture non dovevano mai essere di seta, dovevano avvolgere il corpo davanti. Erano proibite le camicie. I mantelli dovevano esser indossati solo d'inverno avere le maniche interamente cucite insieme. Il colore era sempre nero, anche per la biancheria: al massimo tollerava un grigio poco lontano dal nero, per evitare qualsiasi apparenza di lusso e di mollessa. Proibiti restavono mantelli di cuio, calze tessute a mano, scarpe con fibbre, fazzoletti di seta, pellicce sopra i vestiti (solo permessi a malati e anziani ma sempre sotto la tonaca)... A nessuno era permesso indossare abiti più corti durante i viaggi, e i mantelli di viaggi utilizzati per il freddo o la pioggia dovevano essere d'un taglio del tutto semplice. Veniva pure regolato il taglio dei capelli." Rocca i. m. 456-458. A szerző, Luigi Amigoni hivatkozásai további illusztrációkra: L'Ordine dei Chierici Regolari Somaschi nel IV centenario dalla sua fondazione: 1528-1928. Roma 1928; Luigi Zambarelli: Iconografia di S. Girolamo Emiliani. Rapallo 1938.

18 „Imago a vobis mihi transmissa («religioso 1616») certe videatur facies Petri Pazmani. Sed nescio quid album vestimentum suum significet. Habitus novitiorum? In Congregatione nostra nullum habemus documentum hoc comprobantem. Novitii nostri nigram vestem induebant cum corii cingulo pendente usque ad pedes; et pallio similiter nigro. Fontes nunquam loquuntur de alba veste pro novitiis. Puto istam tabulam pictam vere imaginem Petri exprimere, cum aliquo albo vestimento induto a Religioso ... frigoris causa?" P. Maurizio Brioli C.R.S. rendi főlevéltáros (Archivio Generalizio - Sezione Storica Chierici Regolari Somaschi) készséges tájékoztatása (2010. december).

19 Részletesen adatolva: Tusor i. m. (1.j.) - A Pázmányt bíborosként ábrázoló és őt a szomaszka rend tagjaként feltüntető, egyértelmüen propagandisztikus célú „fantáziafestmények" összegyüjtése külön kutatás feladata lehet. Vö. Koltai András: Privigyétől Rómáig. Mösch Lukács és Rátay Egyed kéziratos útleírásai. Magyar Könyvszem- le CXII. 1996, 494-508, 505. Eszerint Rátay Egyed piarista 1760-ban feljegyezte, hogy a velencei szomaszka kolostorban egy Pázmányt ábrázoló festményt látott. Egy cremonai példány lelőhelye: Fondazione Città di Cremona (Inv. Dipinti n. 82), $103 \times 77$ cm, olaj, vászon; 17 . századi cremonai festő munkája.

20 A Kúria a Peretti- és az Aldobrandini-korszakhoz hasonlóan a Borghese-pontifikátus alatt is erősen kifogásolta a magyar államegyházi gyakorlat sajátosságait, bár óvakodott túlságos feszegetésüktől. Fraknói Vilmos: Magyarország egyházi és politikai összeköttetései a római Szentszékkel, III. Budapest 1903, 221-227, 260-261, 283-285 (utóbbira 1. pl. az Államtitkárság néhány jegyzékét a nunciushoz 1609-1610-ből: Biblioteca Apostolica Vaticana (BAV), Barb. Lat., vol. 5929, pag. 203-206; vol. 5931, pag. 284-287, 360-362, 421-423, 736-737).

21 Itt jegyzem meg, hogy Pázmánynak olyan hiteles ábrázolása, amely pusztán (megerősített, beiktatott, felszentelt) érsekként ábrázolná, nincsen. Csak choralis öltözékü, bíborosi portréi maradtak ránk.

22 Részben talán a prímási méltóságot övező különleges figyelem miatt utóda, a már felszentelt püspök Lósy Imre például szükségesnek tartotta, hogy külön brévében kérjen engedélyt megerősítése előtt a főpapi funkciók végzésére (, pontificalia exercere”). L. levelét Francesco Barberinihez, Pozsony, 1637. december 5. BAV Barb. Lat., vol. 6894 , fol. 1 rv.

23 A vonatkozó adatok kiadott levelezésében: Hanuy Ferenc (kiad.): Pázmány Péter... összegyüjtött levelei I-II. Budapest 1910-1911, I., n. 33. skk.

24 Csupán jegyzetben hozom azt a megfigyelést, hogy a 2. sz., fehér mozzettás kép az 1. számúval ellentétben Pázmányt már szakállal ábrázolja. Az arcszőrzet a festményen - hossza, dús volta alapján - legalább félévesnek tünik.

25 Lukács László: Jezsuita maradt-e Pázmány mint érsek? In: Pázmány Péter emlékezete... i. m. 197-267, 212 (65. j.).

26 Pázmány nem címzetes, hanem reális prépostnak számított. Az ilyesfajta - és a 16. század második felére már szokványosnak mondható, szerintem (is) a kommendátori rendszerből kinövő - uralkodói javadalomadományozás jogi alapját a történeti összefüggéseket is behatóan tárgyaló Bánk József az 1548/12. tc-ben találta meg. Továbbá hangsúlyozza az efféle beneficiumok esetében a szerzetesi eredetet: „az apátság és prépostság mint szerzetesintézmény megszünt ugyan, de nem teljesen, mivel címe is, javadalma is, egyházi hivatalhoz kötve a mai napig is fennáll." Bánk József: A címzetes apátok és prépostok újabb jogi helyzete Magyarországon. In: Angyal Pál - Baranyay Jusztin - Móra Mihály szerk.: Notter Antal emlékkönyv. Budapest 1941, 18-74, különösen 1922 és 22-24 (az idézet: 21).

27 Vö. Tusor i. m. (1. j.) Monográfiám egyik fontos tézise annak kimutatása és bizonyítása, hogy Pázmány szomaszka kitérőjének tényleges oka a jezsuiták magyarországi birtokképességét eltiltó 1608. évi 8. tc., amely tiltás értelemszerűen magába foglalta az egyházi javadalmak birtoklását úgy a rendnek, mint egyes tagjainak. Vö. Péter Tusor: Why did Pázmány of the Jesuit Order Become a Somascan? In: Pál Fodor-Gyula Mayer-Martina Monostori-Kornél Szovák-László Takács eds.: More Modoque. Die Wurzeln der europäischen Kultur und 
deren Rezeption im Orient und Okzident. Festschrift für Miklós Maróth zum siebzigsten Geburtstag. Budapest 2013, 529-538.

28 Bánk elemzéséből kiderül, hogy a megkülönböztető öltözék, jelvények viselése mind liturgikus, mind nem liturgikus téren évszázados szokásjog volt Magyarországon. Szabályozását már 1711-ben szükségesnek látta Keresztély Ágost. Az is kiderül, a viszony a korábbi szerzetesrendi előzményekkel még a 17. század derekán is képlékeny, épp a rendi elöljárói: apáti, préposti jelvények használata kapcsán. Mindez akkor is nagyon fontos közlés, ha az 1648-as zsinat tematikájában a kérdés liturgikus összefüggésben került elő. Bánk i. m. 43-45.

29 Lukács László: Jezsuita maradt-e Pázmány... i. h.

30 IV. Béla 1251-ben alapította. A második adománylevél 1252-ből származik. További irodalommal: Kristó Gyula főszerk.: Korai magyar történeti lexikon (9-14. század). Budapest 1994, Turóc, 963 (itt is köszönöm Bácsattyai Dániel készségét); Kovács-Legeza-Török i. m. 18-19 és 44.

31 II. Ulászló egykori kancelláriai jegyzője, a Fegyverneky Ferenc-féle reformot is segítő Majthényi Uriel (15061541) a prépostság javait 300 forint évdíj fejében 1534 1535 folyamán adta zálogba Révay Ferencnek. A szerzetesek 1554-ben távoztak végleg. Vö. Rupp Jakab: Magyarország helyrajzi története I-III. Budapest 1870-1876, I., 673-683; illetve Honismeret XXXII. 2004/6. sz.; Bánk i. m. 23. Kovács-Legeza-Török i. m. 44 szerint Majthényi 1550-ig volt prépost, a prépostságot a Révaiak 1529-1544 között tartották megszállva és többször kifosztották.

32 Megjegyzendő még, hogy a vélhetően korábbi írásos emlékekből merítö Diarium Thurociensis Residentiae Socieatatis Iesu ab anno 1666 a premontrei múltat gondosan számon tartó visszatekintésében 1568-ból Oláh Miklóst, 1585-ből Radéczi István nyitrai püspököt említi „administrator et commendatarius" -ként. Magyar Nemzeti Levéltár, Országos Levéltár (MOL), Magyar Kamara Archivuma (MKA), Acta Iesuitica (E 152), Irregestrata, 224 d., 1. tétel, n. 2.

33 1629-es monaszterológiájának alapismeretei vélhetően az érseksége előtti évekre nyúlnak vissza. Vö. Acta et Decreta Synodi Diocesanae Strigoniensis... Anno Domini M.D XXIX, Pottendorf 1667 (App. II.).

34 Ezt a folyamodvány 5. pontja fejtegeti. (Fontos még a 2. pont, amely az 1541/12. és az 1550/19. tc. hivatkozva a premontreiek által elhagyott turóci prépostság oktatási célú hasznosítását sürgeti.) Statuum et ordinum catholicorum supplicatio in Hungaria ad regem Matthiam II, ut patres Iesuitas in suam protectione et curam suscipiat rex, eosque in suis bonis et iuribus observet, ac ut iuxta regales locum suum inter status et ordines retineat. Anno 1610 porrecta. MOL, MKA, Acta Iesuitica (E 152), Irregestrata, 224 d., 1. tétel, n. 3.

35 Ahol szintén számon tartották Turóc premontrei eredetét, és Pázmány halála után megpróbálták visszaszerezni a prépostságot: „praepositum Sztrakoviensem Pragae ordinis Praemonstratensis instare suo supplici libello apud Caesaream maiestatem, ut praepositura Thurociensis a nobis auferretur et ordini Praemonstratenisum restitueretur." Dobronoky György 1637. március 25-ei bejegyzése diáriumában. Eötvös Loránd Tudományegyetem Könyvtára, Kézirattár, Collectio Prayana, tom 30. Vö. Báthory Orsolya: Dobronoki György S.J. latin nyelvü diáriuma. In: Pázmány Péter és kora. (Pázmány
Irodalmi Mühely. Tanulmányok, 2. Szerk.: Hargittay Emil) Piliscsaba 2001, 372-394, 376, 17. j. - Puszta hipotézis, de nem megalapozatlan, hogy a prágai premontreiek éppen Pázmány ott publikált kinevezése kapcsán tudatosították Turóc premontrei eredetét. Ennél kézenfekvőbb alkalom aligha kínálkozott, bár a rendnek valami kapcsolata korábban is megmaradt Turóccal, de erre csak De Mara nuncius utalásából tudunk. L. 1613. március 22-ei jelentését, BAV, Barb. Lat., vol. 6920, fol. 39rv.

36 Abt Raimund Schreier O.Praem. (Stift Wilten, Ausztria) szíves közlése a számára átküldött Pázmányportré kapcsán: „Der durchgehende Kragen, also nicht geknöpft, ist typisch für die Zeit vor 1650 in unserem Orden. $\mathrm{Zu}$ einem derartigen Kragen gehört auch solch große Kapuze (wie Mondaye heute noch hat), damit man die Kapuze über den Kopf ziehen kann... bei einer Publikation können Sie sinnvoll Ihre These vom Propost von Turoc vortragen." - A capucinum a mozetták többségénél mind szimbolikusabbá vált, végül prelátusok esetében a pápai Államtitkárság 1969-ben eltörölte használatát. (XVI. Benedeknél azonban újra feltünik.) Secrataria Status seu Papalis instructio circa vestes, titulos et insignia generis Cardinalium, Episcoporum et Praelatorum ordine minorum. Acta Apostolicae Sedis LXI. 1969, 334-340. (A Pázmány-festmény értelmezésénél szándékkal kerültem a rochetum szót. Ez ma, úgy tünik, a pápai, föpapi, papi reverenda vállgallérját jelenti. Uo.)

37 Számos kép az apátság honlapján: http://www. mondaye.com (Vö. az előző jegyzetet.)

38 A mozzetta önmagában elég lehetett a préposti méltóság reprezentálására. Unterzell bei Würzburg prépostja például csak 1700 körültől viselt pectoralét, ami tehát nem volt rangja kifejezésének elengedhetetlen kelléke. Ugyancsak Abt Raimund Schreier O.Praem. közlése.

39 Vö. Bánk i. m. 43-45.

$40 \mathrm{Az}$ első ilyen aktus említése 1388-ból maradt fenn, 1404-től pedig általánosnak tekinthető a gyakorlat. Kovács-Legeza-Török i. m. 24-25.

41 Vö. Tusor i. m. 2013 (27. j.), 529-538.

42 A turóci nemesség már 1538-ban a hiteleshely viszszaállítását sürgette, akkor még hiába. Kovács-LegezaTörök i. m. 22-23 és 44. - A Bethlen-féle támadások idején szünetelö társaskáptalan (,sacerdotes catholici in illo Conventu Thurociensi degentes") működését Pázmány 1626-ban álltotta helyre. Levele Turóc vármegyéhez, Vágsellye, 1626. július 24. Hanuy i. m. I., n. 350. L. még: II., n. 784., 806., 822. (ahol a címzett Prachár Miklóst Pázmány "conventuali nostro B.M.V”-ként titulálja).

43 Ez inkább csak elméleti feltételezés részemről. Pázmány Péter 1617. január 14-én, érseksége kezdetén a turóci konvent számára kiadott, viszonylag részletes, kiadatlan, a végén s.k. aláírt („Petrus Pazmany archiepiscopus Strigoniensis") és közben javított utasításában (Instructio conventualium Beatae Mariae Virginis de Thurocz per illustrissimum ac reverendissimum dominum Petrum Pazman archiepiscopum Strigoniensem etc. facta et emanata Posonÿ in curia archiepiscopali die decima quarta mensis Ianuarii, anno Domini 1617) nem szól a tagok ruházatáról, ami inkább arra utal, hogy a plébániákat is ellátó konvent-tagok öltözéke nem különbözhetett a világi papságétól. A havonta felolvasni s.k. rendelt („Hanc instructionem singulis mensibus legant in conventu") - gondos szentségkiszolgáltatást eloíró, kocsmázást, 
illetlen játékokat stb. tiltó - dokumentum mindazonáltal szép példája az elterjeszteni szándékozott katolikus konfesszionális diszciplinaritásnak, illetve bizonyítja számunkra Pázmány turóci prépostságának valós jellegét. MOL, MKA, Acta Iesuitica (E 152), Coll. Tyrn., Reg., fasc. 21, n. 24 (103. cs., 69-72. fol.).

44 Nem mellékes érdekességként jegyzem meg, hogy Pázmány turóci préposti kinevezésének időszakában Johann Lohel prágai érsek (1612-1622), aki eredetileg premontrei szerzetes volt, ugyanilyen fehér, a korabeli forrásokban mantellettónak nevezett vállgallért hordott, többek között a császári udvarban is, ahol bizonyára gyakran megfordult. Éppen 1616 első felében kérte, hogy öltözetét az érseki rangjához illendőbb lilára cserélhesse: „Con lettere, de quali vien qui la copia ha fatto instanza monsignor arcivescovo di Praga, che gli si conceda poter portare il mantelletto pavonazzo in luogo del bianco, che come dell'ordine premonstratense portava da pueritià. Ma sua beatitudine non ha voluto per ancora venirne alla deliberazione aspettando prima d'intendere il parer di vostra signoria, la quale potrà però avvisarcelo." Scipione Borghese Placido De Marához, Róma, 1616. február 27. Archivio Segreto Vaticano (ASV), Fondo Borghese, Serie I, vol. 945, fol. 33rv. Az Államtitkárság június 25-ei jegyzékében engedélyezte az érseki öltözék színének megváltoztatását, miután a nuncius március 21-ei válaszában kedvező véleményt adott. Uo. fol. 109rv és BAV, Barb. Lat., vol. 6921, n. 63 (vö. n. 88 is). Nem tartom kizártnak, hogy a fehér vállgallér felöltésének ötlete a prágai érsek viseletében gyökeredzik. A premontreiek „vállalhatóságát" nagyban növelte, hogy ekkoriban folyt cseh- és morvaországi reformjuk. Vö. Caspar Questenberg leveleit V. Pálhoz és Borgheséhez, Prága, 1616. július 4. ASV, Segretario di Stato, Particolari, fol. 64r-67v.

\section{THE “ENIGMA” OF THE EARLIEST PÁZMÁNY PORTRAIT}

The earliest authentic representation of Péter Pázmány is registered by special literature as his portrait as a Somascan monk. It is based on the white hooded garment Pázmány is wearing in the picture. It is obviously not part of a Jesuit's or an archbishop's or cardinal vestments. The interpretation as Somascan, the source of which is the handwritten catalogue of the Pannonhalma collection which preserves the picture, was probably based on the preclusion of other possibilities. To refute this assumption, there are more than one arguments. We know that Pázmány was not entitled to put on the Somascan habit - which was otherwise taken for him from Rome to Prague in July 1616 because his de facto admission into the order was held up (and finally cancelled), and more important still, we can cite Lodovico Ridolfi, chargé d'affairs of the Habsburgs house in Rome, claiming that the habit of the Somascans did not practically differ from that of the Jesuits. In the pertinent catalogue edited by Giancarlo Rocca only a black habit differing in cut from the habit of the Jesuits is mentioned. Upon our inquiry the central archivist of the order P. Maurizio Brioli C.R.S. also answered he had no idea of the white garment in the picture, and there was no trace of it in the order's documents, including the clothes of the novices. Consequently, the depicted habit cannot be Somascan. In the enumeration of Pázmány's earlier positions a post was overlooked, which may be the clue to the solution. It is the provostship in Turóc. Turóc was originally founded by the Premonstratensians, and the Hungarian members of that order were wearing a white mozzetta of a similar cut to Pázmány's in the painting as late as the $18^{\text {th }}$ century. Most probably, Pázmány had to emphasize, also in externalities, mainly during his 1616 summerdiplomatic missions, particularly when facing the Protestant estates, that he was no Jesuit any longer (and hence was liable to take the archiepiscopal chair under the act of 1608). He could hardly have done it in a more evident manner than wearing this white mozzetta, which simultaneously expressed a monastic and a prelatic character. It is interesting, however, that at the time of the painting of the picture - dated between the beginning of his provostship at Turóc on 25 April 1616 and 28 September, Pázmány as a candidate for novitiate was temporarily the member of the Somascan order de iure canonico. Under the white mozzetta with capucinum of Premonstratensian origin he is wearing however a Jesuit's habit with the collar and there is a biretta similar to the Jesuits' on his head.

Tusor Péter történész / historian, Piliscsaba, Pázmány Péter Katolikus Egyetem, Bölcsészet- és Társadalomtudományi Kar, Történettudományi Intézet / Pázmány Péter Catholic University, Faculty of Humanities and Social Sciences, Institute of History, tusor.peter@btk.ppke.hu

Kulcsszavak: Pázmány Péter, Pázmány-ikonográfia, jezsuita rend, szomaszka rend, premontrei rend, turóci prépostság, esztergomi érsekség / Keywords: Péter Pázmány, Pázmány iconography, the Society of Jesus, the Somascan order, the Premonstratensian order, the provostship of Turóc, archbishopric of Esztergom 